\title{
Analysis of Factors that Affect Employee Work Accidents at PT. Windu Blambangan Sejati (WBS) Banyuwangi Regency 2018
}

\begin{abstract}
Ruri Firmansyah $^{1}$, Sismulyanto ${ }^{2}$, Nur Wijayanti ${ }^{2}$

${ }^{1}$ Magister of Health Study Program of Institut Ilmu Kesehatan STRADA Indonesia

${ }^{2}$ Lecturer of Institut Ilmu Kesehatan STRADA Indonesia

Email:

rurifirmansyah123@gmail.com

Received: October 12, 2019

Workplaces always have various hazard factors that can affect the health of the workforce or can cause work-related disorders or illnesses. Accidents, the essence is an unexpected event and certainly not expected by anyone. These unexpected events, obviously not a form of intentional and not planned in advance. Accidents arise as a result of managing potential hazards and risks to low occupational safety and health. The purpose of the study was to analyze the factors that influence employee work accidents at PT. Windu Blambangan Sejati (WBS) Banyuwangi Regency. The research design used was cross sectional. The research population is all employees of PT. Windu Blambangan Sejati (WBS) Banyuwangi Regency and a large sample of 81 people using simple random sampling. Data collection using questionnaire sheets was then analyzed using logistic regression tests. The results showed that there was an influence of skills on workplace accidents ( $\mathrm{p}$-value $=0.027<0.05)$. There is an influence of experience on workplace accidents ( $\mathrm{p}$-value $=0.043$ $<0.05)$. There is an influence of discipline on workplace accidents (p-value $=0.040<0.05)$. There is an influence of Technical factors (availability of equipment) on workplace accidents ( $p$ value $=0.003<0.05)$. There is no effect of lay out on work accidents ( $\mathrm{p}$-value $=0.420>0.05$ ). There is no effect of lighting on work accidents ( $\mathrm{p}$-value $=0.944>0.05$ ). There is no noise effect on work accidents ( $p$-value $=0.084>0.05$ ). Based on these studies, company management pays more attention to these three factors, namely human, technical and environmental by conducting periodic and periodic maintenance.
\end{abstract}

Accepted : February 13, 2020

Published : May 10, 2020
Keywords: Human factors, technical factors, environmental factors, workplace accidents

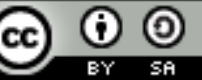

This is an open-acces article distributed under the terms of the Creative Commons Attribution-ShareAlike 4.0 International License. 


\section{INTRODUCTION}

Workplaces always have various hazard factors that can affect the health of the workforce or can cause work-related disorders or illnesses. This disorder can be physical or psychological disorders of the workforce. In general, the hazard factors of the work environment can originate or come from technical, environmental and human factors (Tarwaka, 2014). The optimum level of loading intensity will be achieved, if there is no excessive pressure and tension both physically and mentally. Pressure is concerned with several aspects of human activities, tasks, organizations, and the environment that occur due to the reaction of individual workers because they do not get the appropriate desires (Tarwaka, 2014).

Based on data from the International Labor Organization (ILO) in 2013, one worker in the world dies every 15 seconds due to workplace accidents and 160 workers experience work-related illness. The previous year (2012) the ILO recorded a mortality rate due to accidents and occupational diseases (PAK) of 2 million cases each year. In addition, the results of the report on the implementation of occupational health in 26 provinces in Indonesia in 2013, there were around 2,998,766 cases of general illness in workers, and 428,844 cases of work-related illnesses (Ministry of Health, 2014). According to Setiajit, the head of the East Java Department of Manpower and Transmigration said that East Java had an accident due to in a year in 2017, there were 14,552 work accidents in the area of the company. While accidents outside the company's area reached 1,755 cases (Detiknews, 2017).

Accidents, the essence is an unexpected event and certainly not expected by anyone. These unexpected events, obviously not a form of intentional and not planned in advance. In the event of a work accident or accident due to work, it will always be related to the work relationship, namely as a result of work or when carrying out a job, including accidents that afflict workers on the way to or returning from work. Accidents arise as a result of managing potential hazards and risks to low occupational safety and health. hazards and risks can be sourced from tools and materials, machines used, work processes, unsafe work environments, limitations of workers, low worker safety behavior, non-ergonomic work conditions, and organizing work, and a non-conducive work culture (Kurniawidjaja, 2011).

This research is important to know the responses of employees and companies about work accidents at the company PT. Windu Blambangan Sejati (WBS) Banyuwangi. Besides that, companies can reduce the occurrence of work accidents and can increase work productivity and can find out what causes work accidents. Therefore, this study raises the theme of the factors that affect employee work accidents, from this theme is expected to be able to provide knowledge to companies and employees to be able to reduce the level of workplace accidents that often occur.

From the above phenomena and problems, the author is interested in examining the factors that affect employee work accidents at PT. Windu Blambangan Sejati (WBS) Banyuwangi. In the proposal the author took the title: "Analysis of the factors that affect employee work accidents at PT. Windu Blambangan Sejati (WBS) Banyuwangi Regency".

\section{METHODS}

The design used in this study is cross-sectional. The population is all employees of PT. Windu Blambangan Sejati (WBS) Banyuwangi Regency, a number of 81 respondents using simple random sampling technique. The research variables are human, technical and environmental. Data was collected using a questionnaire, then the data were analyzed using descriptive analysis.

\section{RESULTS}

Frequency Distribution Based on Skills

Table 1. Frequency Distribution Based on Skills at PT. Windu Blambangan Sejati (WBS) Klatak Banyuwangi Regency on July 16 - 312018

\begin{tabular}{lcc}
\hline Skills & $\mathrm{n}$ & $\mathrm{f}(\%)$ \\
\hline No & 37 & 45,7 \\
Yes & 44 & 54,3 \\
\hline Total & 81 & 100 \\
\hline
\end{tabular}

Source: Primary data for research in 2018 
Based on table 1 shows that of the 81 respondents most had skills (had attended training) in the K3 field as many as 44 respondents $(54.3 \%)$.

\section{Frequency Distribution Based on Experience}

Table 2. Frequency Distribution Based on K3 Experience at PT. Windu Blambangan Sejati (WBS) Klatak Banyuwangi Regency on July 16 - 312018

\begin{tabular}{lccc}
\hline & Experience & $\mathrm{n}$ & $\mathrm{f}(\%)$ \\
\hline No & & 31 & 38,3 \\
Yes & Total & 50 & 61,7 \\
\hline & 81 & 100 \\
\hline
\end{tabular}

Based on table 2 shows that of the 81 respondents most of them had experience (working $>5$ years) that is as many as 50 respondents $(61.7 \%)$.

\section{Frequency distribution based on discipline}

Table 3. Frequency distribution based on discipline at PT. Windu Blambangan Sejati (WBS) Klatak Banyuwangi Regency on July 16 - 312018

\begin{tabular}{lccc}
\hline & Discipline & $\mathrm{n}$ & $\mathrm{f}(\%)$ \\
\hline Not discipline & & 25 & 30,9 \\
Discipline & & 56 & 69,1 \\
\hline \multicolumn{2}{c}{ Total } & 81 & 100 \\
\hline
\end{tabular}

Based on table 3 shows that of the 81 respondents most of the discipline of employees in the use of PPE in the discipline category is as many as 56 respondents $(69.1 \%)$.

\section{Frequency distribution based on Equipment Availability}

Table 4. Frequency distribution based on Equipment Availability at PT. Windu Blambangan Sejati (WBS) Klatak Banyuwangi Regency on July 16 - 312018

\begin{tabular}{lccc}
\hline & Equipment Availability & $\mathrm{n}$ & $\mathrm{f}(\%)$ \\
\hline Bad & & 15 & 18,5 \\
Good & Total & 66 & 81,5 \\
\hline & 81 & 100 \\
\hline
\end{tabular}

Based on table 4 shows that of the 81 respondents most of the availability of equipment is in the good category as many as 66 respondents $(81.5 \%)$.

\section{Frequency distribution based on Lay Out}

Table 5. Frequency distribution based on Lay Out at PT. Windu Blambangan Sejati (WBS) Klatak Banyuwangi Regency on July 16 - 312018

\begin{tabular}{lccc}
\hline & Lay Out & $\mathrm{n}$ & $\mathrm{f}(\%)$ \\
\hline Not correct & & 13 & 16,0 \\
Correct & Total & 68 & 84,0 \\
\hline & & 81 & 100 \\
\hline
\end{tabular}

Based on table 5 shows that of the 81 respondents most of the workplace layouts are in the appropriate category, namely as many as 68 respondents $(84.0 \%)$.

\section{Frequency distribution based on lighting}

Table 6. Frequency distribution based on lighting at PT. Windu Blambangan Sejati (WBS) Klatak Banyuwangi Regency on July 16 - 312018

\begin{tabular}{lccc}
\hline & Lighting & $\mathrm{n}$ & $\mathrm{f}(\%)$ \\
\hline Bad & & 12 & 14,8 \\
Good & Total & 69 & 85,2 \\
\hline & 81 & 100 \\
\hline
\end{tabular}

Based on table 6 shows that of the 81 respondents most of the information in the workplace is in good category, as many as 69 respondents $(85.2 \%)$. 
Frequency distribution based on noise

Table 7. Frequency distribution based on noise at PT. Windu Blambangan Sejati (WBS) Klatak Banyuwangi Regency on July 16 - 312018

\begin{tabular}{llc}
\hline Noise & $\mathrm{n}$ & $\mathrm{f}(\%)$ \\
\hline Yes & 14 & 17,3 \\
Not & 67 & 82,7 \\
\hline Total & 81 & 100 \\
\hline
\end{tabular}

Based on table 7 shows that of the 81 respondents most of the noise in the workplace is not noisy category as many as 67 respondents $(82.7 \%)$.

\section{Frequency distribution based on work accidents}

Table 8. Frequency distribution based on work accidents at PT. Windu Blambangan Sejati (WBS) Klatak Banyuwangi Regency on July 16 - 312018

\begin{tabular}{lccc}
\hline & Work Accidents & $\mathrm{n}$ & $\mathrm{f}(\%)$ \\
\hline Never & & 72 & 88,9 \\
Ever & Total & 9 & 11,1 \\
\hline & & 81 & 100 \\
\hline
\end{tabular}

Based on table 8 shows that of 81 respondents most of the respondents had never experienced work accidents as many as 72 respondents $(88.9 \%)$

\section{DISCUSSION}

\section{Human factors in workplace accidents at PT. Windu Blambangan Sejati (WBS) Banyuwangi Regency \\ Skill factors for workplace accidents at PT. Windu Blambangan Sejati (WBS) Klatak Banyuwangi Regency}

Based on the results of this study indicate that of the 81 respondents most of the category work skills had attended K3 training and had never experienced an accident as many as 43 respondents $(53.1 \%)$, and logistic regression statistical tests with the results of $\mathrm{p}$-value $=0.027$, which means $<0.05$, so H1 is accepted and Ho is rejected, which means there is an influence of skills on workplace accidents at PT. Windu Blambangan Sejati (WBS) Klatak Banyuwangi Regency.

The results of the research conducted by Kartika (2015) which examined the effect of training on health and work safety (Study on Production Department Employees at CV. Bangkit Sukses Makmur). The purpose of this study was to determine the effect of training methods on occupational health and safety on the CV. Bangkit Sukses Makmur, to find out the effect of training material on occupational health and safety, to determine the significant effect between training methods and training materials on health and safety. The results of the analysis found that there was a significant influence between the training method variables on the variables of occupational safety and health of employees of 0.493 . Second, there is a significant influence between the training material variables on the variables of occupational safety and health of employees of 0.331 . Whereas the latter has a significant influence between the training method variables and training material simultaneously on the variables of occupational safety and health of employees at 0.392 (Adjusted R square).

According to Ridley (2006), accidents do not occur, but are caused by weaknesses on the part of the company, workers or both. The consequences can cause trauma to workers, injuries can affect their personal, family and quality of life. As for the company, in the form of loss of time wasted on investigations and the worst costs for legal proceedings. According to Husni (2010: 152), the causes of workplace accidents can be categorized into four factors, namely: 1) Human Factors, for example due to lack of skills or lack of knowledge, misplacement; 2) Factors of material / materials / equipment, for example materials that are supposed to be made of iron, but to make it cheaper to be made from other materials so that it can easily cause accidents; 3 ) Hazard / source of danger factors, there are two reasons, namely: dangerous actions: for example due to wrong methods of work, fatigue / lethargy, imperfect work attitude and so on; and dangerous conditions / conditions: i.e. unsafe conditions of machinery / equipment, environment, process, nature of work; 4) Factors faced, for example lack of maintenance / maintenance of machines / equipment so they cannot work perfectly. 
The results showed that the skills possessed by the employees at PT. Windu Blambangan Sejati (WBS) Most of the Klatak of Banyuwangi Regency have participated in K3 skill activities. The existence of skills, at least can increase employee knowledge about occupational safety and health so that they can work, employees will put forward more careful attitudes and behavior. This fact is also supported by the education that is owned by employees, most of whom have high school education (46.9\%) and tertiary education (9.9\%). The higher education the employee has, the easier it will be to receive instructions given by the company so that safety and health can work well and work can be avoided from workplace accidents. Therefore, the existence of these skills, employees can work with professionals

\section{Factors in work experience on workplace accidents at PT. Windu Blambangan Sejati (WBS) Klatak Banyuwangi Regency}

Based on the results of this study indicate that of the 81 respondents most had work experience (working period $>5$ years) and had never had an accident as many as 43 respondents $(53.1 \%)$, and logistic regression statistical tests with the results of $p$-value $=0.043$, which means

$<0.05$, so $\mathrm{H} 1$ is accepted and Ho is rejected, which means there is an influence of experience on workplace accidents at PT. Windu Blambangan Sejati (WBS) Klatak Banyuwangi Regency.

The results of research conducted by Martiwi (2017) which examined the factors causing work accidents in building construction. The results of the analysis show that the respondents who experienced work accidents $\mathrm{had} \geq 30$ years of age $(52.2 \%)$, low education level $(91.3 \%)$, working period $\leq 5$ years $(65.2 \%)$, working hours $>8$ hours $(100 \%)$, low level of knowledge $(56.5 \%)$, fatigue with tired categories $(82.6 \%)$, and safe use of PPE $(100 \%)$. The conclusion in this study is that human factors (workers) have an influence on the occurrence of workplace accidents. All activities or daily activities are things that will become an experience, both good experiences and bad experiences. So keep this experience happening for every employee who works in a company, namely the experience they can in doing work in a company. Experience is part of the knowledge possessed by an employee to support something. So there needs to be good intelligence (Mangkunegara, 2012). Experience in work is usually obtained from the length of time the employee works, both from the company where the employee works now, and from where the employee worked before. Experience aimed at alertness to workplace accidents will be better if viewed from the length of time the employee works in the company. Because the longer the employee works, the more experience he gets.

The results of the study indicate that work experience has a relationship with workplace accidents. The longer the employee works, the more expert and proficient in carrying out the tasks given by the company. In terms of working professionalism, of course there are differences between employees who have just worked with those who already have experience ( $>5$ years of work). For new employees, they have a tendency to be inattentive attitude and behavior at work so they can increase the trigger factors for workplace accidents in the company. Another case with employees who already have a long enough work period so that employees are more alert and careful in working, because experience is the best teacher in doing everything, especially concerning the problem of workplace accidents. Besides that, the employees at work do not feel burdened with the density of activities that must be done because they already feel accustomed to completing their workload.

\section{Factors Work discipline for workplace accidents at PT. Windu Blambangan Sejati (WBS) Klatak Banyuwangi Regency}

Based on the results of this study indicate that of 81 respondents most had work discipline (suitability of PPE use) and never had an accident as many as 54 respondents (66.7\%), and logistic regression statistical tests with the results of p-value $=0.040$, which means $<0.05$, so H1 is accepted and Ho is rejected, which means there is an influence of discipline on workplace accidents at PT. Windu Blambangan Sejati (WBS) Klatak Banyuwangi Regency.

The results of this study are similar to the results of previous studies conducted by Savitri (2016) which examined human factors with the occurrence of workplace accidents in the aluminum furniture industry center in North Hulu Sungai Regency. The results showed that 40 people had experienced work accidents. The type of work accident was slipped (11.6\%), punctured (48.8\%), Injured (32.6\%). The injured body part that overwrites is on the hand $(69.8 \%)$. The results showed that there was a relationship between age and education level $(\mathrm{p}<0.05)$ with the occurrence of workplace accidents. 
Control efforts are made by making a comfortable work space, adequate resting schedules, procurement of personal protective equipment (PPE) that is in accordance with the potential hazards that exist.

Discipline is the most important thing for employees, because the better the discipline of employees, the lower the work mistakes they make. Without discipline, it is difficult for company organizations to achieve optimistic results. Good discipline reflects a person's responsibility for the tasks given to him. This encourages work enthusiasm, morale, and the realization of goals set by the company. Work discipline can be defined as a form of employee self-control and regular implementation, which shows the level of seriousness of the workforce team in the organization (Simamora, 2010).

The results of the study indicate the existence of a relationship between human factors is a work discipline with workplace accidents. This is due to negligence, failure and lack of knowledge of workers regarding $\mathrm{K} 3$ so that this results in the occurrence of workplace accidents. Based on the results of research in table 4.3 shows that the lack of workplace accidents in the company is influenced by the presence of discipline in work. The existence of this work discipline can increase one's awareness and willingness to comply with all applicable company regulations and social norms. To suppress the occurrence of workplace accidents, the company should incessantly remind employees to be disciplined in carrying out their work.

\section{Technical factors for workplace accidents at PT. Windu Blambangan Sejati (WBS) Banyuwangi Regency}

Based on the results of this study indicate that of the 81 respondents most of the availability of equipment in good categories and never had accidents as many as 63 respondents $(77.8 \%)$, and statistical logistic regression test with the results of $p$-value $=0.003$, which means $<0.05$, so H1 is accepted and Ho is rejected, which means there is an influence of Technical factors (availability of equipment) on workplace accidents at PT. Windu Blambangan Sejati (WBS) Klatak Banyuwangi Regency. The results of this study are similar to the results of previous studies conducted by Piri (2012) which examined the effect of health, training and the use of personal protective equipment against workplace accidents in construction workers in the city of Tomohon. The results showed that health factors, training and the use of personal protective equipment had a negative relationship with workplace accidents, which increased the value of these three factors.

The results of this study are similar to the results of a previous study conducted by Zahara (2017) which examined the compliance with personal protective equipment (PPE) in terms of knowledge and behavior in the Installation of Hospital Facilities and Infrastructure Maintenance officers (IPSRS). The results showed a correlation between compliance using PPE personal protective equipment knowledge ( $\mathrm{p}$ value $=0,001)$, and behavior ( $\mathrm{p}$ value $=0,006$ ). The RSUD is expected to be able to implement more stringent Operational Procedure Standards (SPO), conduct training on the use of PPE, and improve supervision of officers' compliance in using PPE.

The results of this study are similar to the results of previous research conducted by Raodhah (2014) who examined the factors associated with the use of personal protective equipment in the employee packer part of PT Semen Bosowa Maros in 2014. The results of research at PT. Bosowa Maros Semen shows that knowledge, K3 training and policies affect the use of PPE where the value of $p=0.000, p=$ 0.000 and $p=0.000(p \leq 0.05)$, while the availability of PPE and supervision does not affect the use of PPE where each - each variable is $p=0.241$ and $1.523(p>0.05)$.

Accidents do not happen by accident, but there is a reason. Because there is a cause, the cause of the accident must be investigated and discovered, so that further with corrective actions aimed at that cause and with further preventive efforts accidents can be prevented and similar accidents do not recur (Suma'mur, 2009).

According to Notoatmodjo (2010), availability or enabling is a facility in the form of health facilities and infrastructure aimed at empowering workers to be able to hold health facilities and infrastructure for them. In Law No. 1 of 1970 article 14 point $\mathrm{c}$ states that the management (businessman) is obliged to hold for free, all required personal protection equipment for the workforce under his leadership and provide for everyone else who enters the workplace, accompanied by instructions instructions needed according to the instructions of the supervisor or work safety experts.

The results showed that there was an influence between the availability of K3 equipment and the occurrence of workplace accidents. Companies that maintain equipment periodically and periodically can reduce the number of work events in the company. Based on table 4.6 shows that of the 81 
respondents most of the availability of equipment is in the good category as many as 66 respondents $(81.5 \%)$. This indicates that the company is very concerned about the safety and health of its employees. Because if an accident happens to the company not only the employees who lose but the company will also receive the impact of the accident, not even the company often gets a warning from the related manpower agency. Therefore. If this maintenance is ignored not only the gross impression that is the result but the safety of the workforce will be disrupted. Can be imagined if the machine is damaged, then there will be a large loss for the company and labor.

\section{Environmental factors for workplace accidents at PT. Windu Blambangan Sejati (WBS) Banyuwangi Regency \\ Factor lay out for work accidents at PT. Windu Blambangan Sejati (WBS) Klatak Banyuwang Regency}

Based on the results of this study indicate that of the 81 respondents most of the layouts in the workplace are appropriate categories and have never experienced accidents as many as 61 respondents $(75.3 \%)$, and logistic regression statistical tests with the results of $p$-value $=0.420$, which means $>0.05$, so $\mathrm{H} 1$ is rejected and Ho is accepted which means there is no influence on lay out on workplace accidents at PT. Windu Blambangan Sejati (WBS) Klatak Banyuwangi Regency.

The results of this study are similar to the results of a previous study conducted by Transiska (2015) which examined the effect of the work environment and human factors on the level of employee work accidents at PT. Putri Midai Bangkinang Kampar Regency. Based on the test results of the coefficient of determination obtained by the value of R Square in the study, then this value will be changed to form percent. This means the percentage contribution to the influence of the variable Work Environment and Human Factors on Employee Accidents at PT. Putri Midai of Kampar Regency was 62.3\%, while the remaining $37.7 \%$ was influenced by variables not examined in this study.

A good location map is to consider how to get high usage in each room. Therefore there are no rules for the use of unused space, because it will cause confusion in the company. The space layout designer includes decisions about how to organize a room in a physical facility. With the existence of a good space layout, employees will be free from one of the difficulties in carrying out company activities. And employees will be more free to use spaces in the company (Ahyari, 2010). The results of the study show that the layout (lay out) in PT. Windu Blambangan Sejati (WBS) The Klatak of Banyuwangi Regency is in accordance with health and safety conditions. The arrangement or design of a good workplace can support and increase employee motivation in work, because between employees with one another do not clash with each other and have been positioned by the company in such a way that this can occur overlapping in doing tasks that can lead to occurrence work accident.

\section{The lighting factor for workplace accidents at PT. Windu Blambangan Sejati (WBS) Klatak Banyuwangi Regency}

Based on the results of this study indicate that of the 81 respondents most of the information in the workplace was good and never had an accident as many as 63 respondents (77.8\%), and logistic regression statistical tests with the results of $p$-value $=0.944$, which means $>0,05$, so H1 is rejected and Ho is accepted, which means there is no effect of information on workplace accidents at PT. Windu Blambangan Sejati (WBS) Klatak Banyuwangi Regency.

The results of this study are similar to the results of previous studies conducted by Faris (2014) which examined the influence of labor behavior and work environment which moderated work experience factors and education level on construction work accidents in Surabaya. Based on the results of the analysis of labor behavior significantly influence workplace accidents $(\mathrm{R}=0.519)$. While the work environment does not significantly influence workplace accidents $(R=0.003)$, and the education level significantly affects workplace accidents, which before being moderated $\mathrm{R}=0.616$ and after moderating $\mathrm{R}=0.642$. Besides that work experience significantly affects workplace accidents, which before being moderated $\mathrm{R}=0.6$ and after being moderated $\mathrm{R}=0.586$. And the age variable functions as an independent variable and does not function as a moderator variable.

Lighting in work is enough that the light is in our work. The lighting for each employee's workspace within the company established is an important factor in increasing the work productivity of the company concerned. Thus various benefits will be obtained if the company concerned is equipped with an appropriate lighting system in the workspace of each employee of the company. However, this case, 
a thing that is not forgotten in this case is that the right lighting system is not the only determining factor in the operation process. (Ahyari, 2010).

Lighting at PT. Windu Blambangan Sejati (WBS) Klatak Banyuwangi Regency. It is sufficient because lighting that comes from ventilation in the company is not blocked by something so that reflected light from outside the room can go inside. In addition, most employee activities at this company are carried out morning to evening. Only me sometimes if the weather conditions are

cloudy the lighting in the company is assisted by the lights that are already available properly. So that this illumination factor does not have a major influence on the occurrence of work accidents.

\section{Noise factor for workplace accidents at PT. Windu Blambangan Sejati (WBS) Klatak Banyuwangi Regency}

Based on the results of this study indicate that of the 81 respondents most of the noise in the workplace is not noisy and has never experienced an accident as many as 63 respondents (77.8\%), and logistic regression statistical tests with the results of $\mathrm{p}$-value $=0.084$, which means $>0.05$, so $\mathrm{H} 1$ is rejected and Ho is accepted which means there is no influence of noise on workplace accidents at PT. Windu Blambangan Sejati (WBS) Klatak Banyuwangi Regency

The results of this study are similar to the results of previous studies conducted by Andriani (2016) which examined the relationship of age, noise and air temperature with subjective fatigue of individuals at PT X Jakarta. The results of this study indicate that 45 respondents $(88.90 \%)$ experienced mild fatigue, and 5 respondents (11.10\%) experienced moderate fatigue. All respondents who experienced fatigue were exposed to noise and temperature exceeding NAB. The conclusion of this study is that there is no significant relationship between noise $(p=0.31)$ and temperature $(p=0.41)$ air with subjective fatigue, whereas age with subjective fatigue has a significant relationship with the value ( $\mathrm{p}$ $=0.61)$. It is recommended that companies provide policies related to age In carrying out the operation process of a company, generally there will be noise from the machines and equipment used in the company concerned. Actually the noise that occurs in the fertilized space is not desired by the employees, because this will disrupt the peace of work and the peace of work of the employees who work in the company. By setting the sound, it is clear that the worker will no longer depend on the noise coming from the machines or from other places, so he has the full calculation of the officer. In essence, a clean workplace, regular space layout, adequate lighting and controlled noise will contribute to increasing labor productivity. (Ahyari, 2010)

The results showed that there was no relationship between environmental factors and workplace accidents. Environmental factors in this study include 3 things, namely lay out, lighting and noise. From these three components, it can be seen that the layouts in this company are mostly suitable and the lighting is already sufficient so that this can increase the comfort of workers in carrying out tasks that must be done. Besides that, in this company the noise threshold value is below the average of 85 (dBA) so that the working environment in this company can be shown to be very good and representative so that the number of workplace accidents can be reduced to a minimum.

\section{CONCLUSION}

In this study the conclusions can be taken as follows:

There is the influence of skills on workplace accidents at PT. Windu Blambangan Sejati (WBS)

Klatak Banyuwangi Regency ( $\mathrm{p}$-value $=0.027<0.05$ ). There is an influence of experience on workplace accidents at PT. Windu Blambangan Sejati (WBS) Klatak Banyuwangi Regency (p-value $=0.043<0.05)$. There is an influence of discipline on workplace accidents at PT. Windu Blambangan Sejati (WBS) Klatak Banyuwangi Regency ( $\mathrm{p}$-value $=0.040<0.05$ ). There is an influence of Technical factors (availability of equipment) on workplace accidents at PT. Windu Blambangan Sejati (WBS) Klatak Banyuwang Regency ( $\mathrm{p}$-value $=0.003<0.05$ ). There is no influence on lay out for workplace accidents at PT. Windu Blambangan Sejati (WBS) Klatak Banyuwangi Regency (pvalue $=0.420>0.05$ ). There is no effect of lighting on workplace accidents at PT. Windu Blambangan Sejati (WBS) Klatak Banyuwangi Regency (p-value $=0.944>0.05)$. There is no influence of noise on workplace accidents at PT. Windu Blambangan Sejati (WBS) Klatak Banyuwangi Regency

Banyuwangi $(\mathrm{p}$-value $=0.084>0.05)$ 


\section{REFERENCE}

Ahyari. A. 2010. Dasar-dasar Manajemen. Edisi I. Jilid Dua. Yogyakarta. BPFE

Depkes RI. 2014. Satu Orang Pekerja di Dunia Meninggal Setiap 15 Detik Karena Kecelakaan Kerja. Diakses: 02 Mei 2016. http://www.depkes.go.id/article/print/201411030005/

Detiknews, 2017. 14.552 Kasus Kecelakaan Kerja Terjadi di Jatim Sepanjang 2017.

https://news.detik.com/jawatimur/3810738/

Kurniawidjaja M. 2011. Teori Dan Aplikasi Kesehatan Kerja. Jakarta: Penerbit Universitas Indonesia Mangkunegara. 2012. Manajemen Sumber Daya Manusia. Bandung: PT. Remaja Rosdakarya

Notoatmodjo, Soekidjo. 2012. Metodologi Penelitian. Jakarta : Rineka Cipta

Ridley, John. 2008. Ikhtisar Kesehatan \& Keselamatan Kerja Edisi Ketiga. Jakarta: Erlangga

Simamora. 2010. Manajemen Sumber Daya Manusia, Edisi ke-1, Cetakan. Kedua, Yogyakarta: STIE YKPN

Tarwaka. 2014. Keselamatan dan Kesehatan Kerja : Manajemen dan. Implementasi K3 di Tempat Kerja.Surakarta : Harapan Press 